Terakreditasi Ristekdikti: 28/E/KPT/2019

DOI: $10.31538 /$ ndh.v5i2.558

http://e-journal.ikhac.ac.id/index.php/nidhomulhaq

\title{
PENGEMBANGAN KURIKULUM BERBASIS ADIWIYATA UNTUK MENINGKATKAN KEMAMPUAN PRACTICAL LIFE
}

\author{
Didit Haryadi 1), Hendro Widodo ${ }^{2)}$ \\ 1 Universitas Ahmad Dahlan Yogyakarta \\ didit1400008048@webmail.uad.ac.id \\ 2 Universitas Ahmad Dahlan Yogyakarta \\ hwmpaiuad@gmail.com
}

\begin{abstract}
Abstrak
Rendahnya rasa peduli terhadap lingkungan menjadi kebutuhan yang harus dipenuhi melalui pembelajaran nyata. Menciptakan kesadaran dan keterampilan hidup merupakan cara terbaik dalam mewujudkan budaya. Salah satu cara yang perlu ditingkatkan di sekolah adalah dengan sinkronisasi kurikulum yang dapat digunakan untuk meningkatkan kemampuan practical life dalam peduli dan berbudaya lingkungan. Penelitian ini bertujuan untuk mengembangkan kurikulum berbasis adiwiyata dalam membentuk dan meningkatkan kemampuan practical life untuk peduli dan berbudaya. Setting penelitian ini adalah SMP Pangudiluhur Sedayu Yogyakarta dengan subjek kepala sekolah, guru, dan siswa. Metode penelitian ini menggunakan kualitatif dengan pendekatan yang digunakan studi kasus. Teknik pengumpulan data yang digunakan adalah observasi, wawancara dan dokumentasi. Hasil penelitian ini menunjukkan bahwa pengembangan kurikulum berbasis Adiwiyata di SMP Pangudiluhur memiliki ciri khas unik yaitu kurikulum yang disinkronkan dengan adiwiyata untuk meningkatkan kemampuan practical life. Temuan dari penelitian yang sudah dilakukan adalah mengidentifikasi konsep dan membuat kebijakan baru terkait program adiwiyata di lingkungan sekolah.
\end{abstract}

Kata kunci: Kurikulum, Adiwiyata, Practical Life, Peduli, Berbudaya

\begin{abstract}
The low sense of caring for the environment becomes a need that must be met through real learning. Creating awareness and life skills is the best way to create culture. One way that needs to be improved in schools is by synchronizing the curriculum that can be used to improve the ability of practical life in caring and cultured environments. This research aims to develop an adiwiyata-based curriculum in shaping and enhancing the ability of practical life to care and be cultured. The setting of this study is Pangudilubur Sedayu Junior High School Yogyakarta with the subjects of the principal, teachers, and students. This research method uses qualitative approach using the case study. Data collection techniques used were observation, interviews and documentation. The results of this study indicate that the development of Adiwiyata-based curriculum in SMP Pangudilubur has a unique characteristic that is the curriculum that is synchronized with adiwiyata to improve the ability of practical life. The findings of the research that has been done are identifying concepts and making new policies related to the adiwiyata program in the school environment.
\end{abstract}

Keywords: Curriculum, Adiwiyata, Practical Life, Care, Cultured

\section{PENDAHULUAN}

Undang-Undang nomor 32 tahun 2009 pasal 1 ayat 2 menjelaskan bahwa Perlindungan dan Pengelolaan Lingkungan Hidup adalah upaya sistematis dan terpadu yang dilakukan untuk mencegah terjadinya pencemaran dan kerusakan lingkungan hidup yang meliputi perencanaan, pemanfaatan, pengendalian, pemeliharaan, pengawasan, dan penegakan hukum 
melestarikan fungsi lingkungan hidup. Pengembangan kurikulum berbasis adiwiyata adiwiyata berpedoman pada pedoman penyusunan adiwiyata, kesesuaian antara pedoman penyusunan dan implementasi disekolah sangat perlu diperhatikan karena berkaitan dengan kepedulian siswa terhadap lingkungan. Ketika semua komponen sudah berjalan dengan maksimal maka tujuan program adiwiyata sesuai yang diharapkan pemerintah akan terealisasi. Permasalahan sekolah saat ini adalah karena kurangnya penamanan pemahaman untuk peduli dan berbudaya pada lingkungan. Hal ini dibuktikan dengan beberapa data permasalahan lingkungan di wilayah DIY terutama terkait dengan kurang pedulinya terhadap sampah. Data terbaru beberapa tempat pembuangan akhir sampah yang ada di DIY menumpuk salah satunya berada di Piyungan. Hal ini menarik untuk diteliti bagaimana implementasi pengembangan kurikulum berbasis adiwiyata di sekolah menanamkan pemahaman untuk peduli dan berbudaya lingkungan disekolah dan diluar sekolah. Sehingga manfaat dari penelitian ini bisa menjadi acuan dan refrensi baru untuk mengembangkan kurikulum berbasis adiwiyata di sekolah yang lainnya.

Hal ini dikuatkan lagi dengan adanya peraturan menteri (permen) lingkungan hidup No 5 tahun 2013 tentang pedoman penyusunan Adiwiyata (Iswari \& Utomo, 2017, p. 35).

Salah satu yang ada di program Adiwiyata adalah komponen pelaksanaan kurikulum berbasis lingkungan. Menurut (Nasution, 2014) kurikulum merupakan suatu yang untuk mencapai tujuan pendidikan nasional Indonesia yang sudah di rencanakan. Kurikulum dapat di lihat sebagai produk yang dibuat oleh para pengembang kurikulum yang berisi mata pelajaran dan aktivitas yang ada di dalamnya sebagai hal-hal uang di harapkan akan di pelajari siswa, yaitu pengetahuan, sikap, dan keterampilan tertentu.

Pada penelitian terdahulu yang dilakukan oleh dilakukan oleh Rizky Dewi Iswari dan Suyud W. Utomo, mahasiswa Program Studi Ilmu Lingkungan Sekolah, Pascasarjana, UNDIP pada tahun 2017. (Iswari \& Utomo, 2017, p. 39).

Hasil dari riset beberapa sekolah yang sudah menerapkan program Adiwiyata menunjukkan sebesar $48 \%$ tingkat pengetahuan siswa naik, $99 \%$ siswa mempunyai sikap baik terhadap lingkungan, dan $79 \%$ siswa mempunyai tindakan baik terhadap lingkungan. Adapun sekolah yang belum menerapkan program Adiwiyata, sebesar 33\% tingkat pengetahuan siswa naik, 99\% siswa mempunyai sikap baik terhadap lingkungan, dan $76 \%$ siswa mempunyai tindakan baik terhadap lingkungan. Terdapat 
hubungan antara penerapan Adiwiyata dengan pembentukan pengetahuan, sikap, dan tindakan siswa.

Penelitian terdahulu yang dilakukan oleh Nihlawati (2012, p. 12) pada judul Substansi Kebijakan Kurikulum Berbasis Lingkungan pada Sekolah Adiwiyata Di SMP N 2 Kebomas Gresik menunjukkan bahwa di SMPN 2 Kebomas mempunyai kebijakan pengembangan kurikulum berbasis lingkungan, pengembangan yang dilakukan mengembangkan kriteria yang ditetapkan dalam Program Adiwiyata, implementasi pembelajaran PLH menggunakan pendekatan monolitik, integrasi, dan lintas mata pelajaran.

Pembelajaran dengan pendekatan integrasi dilaksanakan pada semua mata pelajaran dan pengembangan diri yang relevan dengan lingkungan. Silabus dan Rencana Pelaksanaan Pembelajaran PLH yang dibuat oleh guru sudah terinternalisasi dengan pendidikan karakter.

Penelitian telaah kurikulum berbasis Lingkungan bertujuan untuk mengetahui letak kelebihan dan kelemahan pada pelaksanaan program Adiwiyata yang bisa dilihat dari output siswa yang peduli lingkungan, diperoleh juga gambaran kurikulum dari sekolah tersebut. Selain itu, melalui penelitian ini juga dapat mengetahui kesesuaian antara komponen yang terdapat di kurikulum sekolah berbasis lingkungan yang akan diteliti dengan kurikulum acuan dari kementerian lingkungan hidup. Manfaat dari penelitian juga untuk mengetahui letak

\section{KAJIAN LITERATUR}

\section{Kurikulum}

Telaah di artikan sebagai penyelidikan, kajian, pemeriksaan, dan penelitian. Telaah biasanya di lakukan pada kurikulum ataupun bahan ajar. Kurikulum dapat juga dipandang sebagai program, yaitu alat yang digunakan untuk mencapai tujuan sekolah. Kurikulum dipandang sebagai harapan yang akan dipelajari siswa, yaitu pengetahuan, sikap, dan keterampilan tertentu. (Nasution, 2014, pp. 8-9).

Menurut Arifin (2012, p. 3) istilah kurikulum dalam pendidikan adalah yang di tempuh dan di selesaikan oleh peserta didik berupa sejumlah mata pelajaran yang untuk memperoleh ijazah. Pengertian ini termasuk tradisional, tetapi paling tidak orang bisa mengetahui dan mengetahui pengertian kurikulum.

Kurikulum merupakan tujuan akhir dari rangkaian proses dan indikasikan oleh perolehan suatu ijazah tertentu kurikulum dianggap sebagai jembatan yang sangat penting untuk mencapainya. Selayaknya seorang atlit lari telah menempuh suatu lintasan panjang dari satu tempat ke tempat lainnya dan akhinya mencapai digaris pemberhentian. Siswa akan mendapatkan 
suatu pegangan berupa buku bahwa siswa telah menempuh kurikulum yang berupa rencana pelajaran yaitu ijazah (Hamalik, $2014: 16)$.

Dinamis merupakan sifat yang harus dimiliki, Perkembangan ilmu pengetahuan dan teknologi, kultur, sistem nilai, tingkat kecerdasan peserta didik, serta kebutuhan masyarakat yang mengalami perubahan sesuai dengan zamannya. Guru seharusnya memiliki wawasan yang mendalam dan luas tentang hal tersebut. Oleh karena itu, tim pengembangan kurikulum di sekolah harus selalu dimonitoring dan dievaluasi untuk menyempurnakan dan memperbaiki kurikulum (Arifin, 2012 :2)

Berdasarkan pendapat para ahli dapat disimpulkan bahwasannya pengertian kurikulum itu sendiri adalah sesuatu yang pegangan yang di rencanakan guna mencapai tujuan pendidikan, atau bisa disebut juga sebagai pedoman bagi pendidik (guru) di dalam kegiatan belajar mengajar. Di dalam Kurikulum biasanya juga memuat suatu tujuan pendidikan yang akan dicapai, dimana dalam pengembangan kurikulum itu sendiri haruslah bersifat dinamis (sesuai dengan perkembangan zaman) (Hakim \& Hasan, 2019, p. 4). Oleh sebab itu guru yang bertindak sebagai pengembang kurikulum dituntut harus memiliki pengetahuan yang mendalam dan luas tentang hal-hal yang ada kaitannya dengan kurikulum.

\section{Komponen Kurikulum}

Menurut Susilo (2007 : 88-89) bahwa komponen kurikulum terdiri atas : 1) Tujuan, 2) Bahan Pelajaran, 3) Proses Belajar dan Mengajar, dan 4) Evaluasi dan Penilaian. Bahan pelajaran, proses belajarmengajar, dan penilaian komponen ini harus saling berkaitan antara satu dengan semua komponen lainnya, jadi tujuan bertalian erat dengan Komponen tujuan

Kurikulum memiliki kerangka dasar, memiliki peranan yang sangat strategis dan penting adalah tujuan, karena tujuan dan memengaruhi dan mengarahkan komponen kurikulum yang lainnya. Penetapan tujuan harus di susun terlebih dalam penyusunan suatu kurikulum.

\section{Komponen Isi atau Materi}

Pengalaman dan kegiatan yang dikembangkan dan disusun dalam rangka mencapai tujuan kurikulum adalah hakikat dari komponen Isi atau materi. Isi kurikulum secara umum dapat bagi menjadi tiga bagian, yaitu: Logika, etika dan estetika ( Susilo, 2007)

Menurut Susilo (2007) Pada umumnya kurikulum pendidikan formal komponen isi/materi disusun dalam struktur kurikulum sesuai dengan tujuan institusional masing-masing dalam bentuk mata pelajaran dan bidang studi. Struktur dapat diatur mata pelajaran pada setiap minggunya serta 
alokasi waktu yang dijadwalkan untuk setiap mata pelajaran.

\section{Komponen Evaluasi}

Evaluasi kurikulum sangat erat hubungannya dengan berbagai kumpulan mata pelajaran atau meliputi semua pengalaman dan kegiatan anak di dalam maupun di luar sekolah dengan definisi kurikulum itu sendiri.

Dari pendapat para ahli yaitu Susilo dan Arifin diatas maka bisa disimpulkan komponen-komponen kurikulum, sebagai berikut;

1) kurikulum yang mengacu kepada segala sesuatu yang ingin dan hendak dicapai disebut Tujuan kurikulum.

2) Isi atau Materi kurikulum berisi;

a. Materi yang diarahkan pada pecapaian tujuan pendidikan nasional

b. Materi yang diarahkan untuk pencapaian tujuan

c. Bahan pelajaran

3) Cara yang ditempuh untuk mencapai tujuan pendidikan disebut Metode atau proses

4) Evaluasi, yaitu untuk mengetahui keefektifitasan kurikulum dalam upaya untuk menyempurnakan serta memperbaiki kurikulum lagi
Komponen evaluasi merupakan salah satu dari komponen kurikulum yang di dalamnya untuk mengukur keberhasilan kurikulum yang sudah dijalankan dan juga akan di tambahkan yang kurang dan diperbaiki yang kurang maksimal.

\begin{tabular}{ccr}
\multicolumn{1}{c}{ Evaluasi } & dilakukan & untuk \\
meningkatkan & kualitas & program \\
kurikululm & berbasis & adiwiyata.
\end{tabular}
Evaluasi salah satu aktivitas yang akan memberikan penilaian akurat terkait kurikulum yang dikembangkan. Berbagai pendekatan evaluasi yang dilakukan diharapkan mampu untuk dapat menjadi tolok ukur keberhasilan dalam pengembangan kurikulum berbasis adiwiyata/

\section{Adiwiyata}

Adiwiyata di artikan sebagai tempat yang ideal dan baik untuk mendapatkan berbagai norma dan ilmu pengetahuan serta etika yang dapat menjadi dasar manusia menuju terciptanya kesejahteraan hidup (Tim Adiwiyata, 2012; 3). Pengertian tersebut dapat dipahami bahwa program adiwiyata untuk sekolah dalam rangka memahami nilai-nilai karakter melalui program pendidikan lingkungan hidup.

Pernyataan di atas didukung oleh Ulfatur (2014) menyatakan bahwa adiwiyata merupakan salah satu prorgram yang 
mendorong terciptanya pengetahuan dan kesadaran warga sekolah dalam upaya melestarikan lingkungan hidup. Program tersebut dimaksud supaya warga sekolah lebih berbudaya dan peduli terhadap lingkungan. Program yang dapat membentuk dan mewujudkan dalam upaya tanggungjawab dan kepedulian terhadap lingkungan

\section{Tujuan adiwiyata}

Program Adiwiyata bertujuan sebagai upaya perlindungan dan pengelolaan lingkungan hidup melalui tata kelola sekolah yang baik untuk mendukung pembangunan berkelanjutan mewujudkan warga sekolah yang bertanggung jawab. (Tim Adiwiyata, 2012: 3). Pengertian tersebut dapat dijabarkan bahwa program adiwiyata merupakan salah satu program sekolah yang dapat meningkatkan pemahaman para warga sekolah terkait dengan lingkungan sekitar. Pembelajaran luar kelas yang dapat dilakukan oleh siapapun demi mendukung Sustainable development goals.

Pengertian di atas sejalan dengan Alpusari (2013) bahwa tujuan adiwiyata adalah menciptakan suatu kondisi dimana para warga sekolah mampu untuk sadar diri dan belajar dari lingkkungan, sehingga warga sekolah turut andil dan bertanggungjawab dalam pengelolaan lingkungan, tidak merusak lingkungan ataupun tidak meremehkan lingkungan. Hal ini sangat dimungkinkan bahwa pembelajaran tidak hanya sebuah teori di dalam kelas, melainkan juga dapat dimaknai sebagai upaya sekolah untuk mampu meningkatkan pengetahuan para siswa melalui program yang ada di luar kelas.

\section{Pelaksanaan Adiwiyata}

Pada pelaksanaannya, menurut Hayati (2017) pendekatan monolitik dan integratif Dalam pembelajaran PLH dapat dilakukan melalui

1) Pendekatan Monolitik

Pembelajaran yang dilakukan melalui satu mata pelajaran disebut Pendekatan monolitik. Dalam pendekatan ini materi lingkungan merupakan mata pelajaran yang diajarkan dalam satu mata pelajaran sendiri sebagaimana mata pelajaran lainnya. Pada pendekatan ini dapat disusun struktur pembelajaran dan pencapaian kompetensi tanpa dikaitkan dengan mata pelajaran lainnya.

Pendekatan Monolitik memiliki keunggulan pembelajaran PLH :

a) Guru tidak akan dibebani untuk pencapaian pengetahuan Pendidikan Lingkungan Hidup yang dititipkan melalui mata pelajaran yang diajarnya. 
Guru hanya diminta bertanggung jawab terhadap pencapaian kompetensi Pendidikan Lingkunag Hidup saja tanpa harus memikirkan pencapaian pengetahuan pada mata pelajaran lainnya.

b) Siswa hanya fokus mata satu palajaran pendidikan lingkungan hidup tanpa harus memikirkan mata pelajaran yang lainya, sehingga siswa dapat konsentrasi untuk memahami secara keseluruhan konsep, pendekatan, dan tujuan pembelajaran PLH.

c) Struktur program pembelajaran dapat disusun berdasarkan kerangka keilmuan secara mandiri, sehingga pencapaian kompetensi dapat terukur dengan jelas. Hal ini memudahkan guru untuk mengembangkan dan menerapkan metode yang efektif guna pencapaian kompetensi yang dimaksudkan.
Namun demikian, Pendidikan lingkungan hidup ini bertujuan lebih kepada membangun perilak, nilai, dan sikap. pendekatan monolitik memiliki kelemahan utama yaitu terjebak pada ranah kognitif. Pembelajaran yang dilakukan hanya bertujuan beorientasi untuk pencapaian materi semata, sehingga tujuan yang diemban pada mata pelajaran PLH diabaikan.

2) Pendekatan Integratif

Salah merupakan satu model dari beberapa model yang dapat diterapkan dalam pembelajaran PLH adalah dengan pendekatan Integratif. Pendekatan integratif ini bisa dilakukan dengan cara menggabungkan pada berbagai bidang studi seperti Pengetahuan Sosial (IPS), Ilmu Pengetahuan Alam, Bahasa Indonesia dan Olahraga. Berbagai mata pelajaran tersebut dipandang dalam suatu ruang lingkup yang saling berkaitan dan luas. Keunggulan Pendekatan ini antara lain:

a. Guru dapat mengembangkan kondisi pembelajaran yang menyeluruh ,utuh, ,dinamis dan bermakna sesuai dengan keinginan dan guru mampu 
menyesuaikan dengan

kebutuhan kemampuan

dan kesiapan siswa.

Pembelajaran seperti ini

mampu memberikan

peluang terjadinya

pengembangan ilmu

pengetahuan yang

berkaitan dengan tema

atau pokok bahasan yang

disampaikan.

b. Mendorong guru untuk mengembangkan

kreatifitas, dalam hal ini, guru diharuskan dan diminta untuk memiliki kreatifitas dan wawasan, pemahaman tinggi karena adanya tuntutan untuk memahami keterkaitan antara satu pokok bahasan yang sedang di ajarkan dengan pokok bahasan lain dari berbagai mata pelajaran.

c. Menghemat tenaga, waktu, dan sarana serta biaya dalam proses belajar mengajar, dapat pula menyederhanakan langkah-langkah pada kegiatan pembelajaran pembelajaran. Hal ini dapat terjadi di karenakan terjadi proses pemaduan jumlah unsur mulai tujuan, materi maupun langkah pembelajaran yang dipandang memiliki kesamaan atau keterkaitan. Selain memiliki keunggulan menggunakan pendekatan integratif pada pembelajaran PLH, pendekatan ini juga memiliki beberapa kelemahan. Salah satu adalah pada aspek kurikulum. Dilihat dari aspek kurikulum, pembelajaran terpadu memerlukan jenis kurikulum yang terbuka untuk pengembangannya. Bersifat luwes harus dimiliki kurikulum, kurikulum harus dapat mencapaian pemahaman siswa terhadap materi (bukan berorientasi pada penyampaian target materi), kurikulum yang memberikan kewenangan sepenuhnya pada guru untuk 


$$
\begin{aligned}
& \text { mengembangkannya baik } \\
& \text { dalam materi, metode } \\
& \text { maupun penilaian dan } \\
& \text { pengukuran keberhasilan } \\
& \text { pembelajarannya. } \\
& \text { d. Memotivasi dan } \\
& \text { mempermudah siswa } \\
& \text { untuk menerima, } \\
& \text { mengenal, menyerap dan } \\
& \text { memahami keterkaitan } \\
& \text { atau hubungan } \\
& \text { antara,pengetahuan, } \\
& \text { konsep nilai atau } \\
& \text { tindakan yang terdapat } \\
& \text { dalam beberapa bahasan } \\
& \text { dalam mata pelajaran. } \\
& \text { Dengan mempergunakan } \\
& \text { model pembelajaran } \\
& \text { terpadu, secara } \\
& \text { psikologik, siswa digiring } \\
& \text { berpikir secara } \\
& \text { mendalam dan luas } \\
& \text { untuk memahami dan } \\
& \text { menangkap hubungan- } \\
& \text { hubungan konseptual } \\
& \text { yang disajikan guru. } \\
& \text { Selanjutnya, siswa akan } \\
& \text { terbiasa berpikir teratur, } \\
& \text { terarah utuh dan } \\
& \text { menyeluruh, analitik dan } \\
& \text { sistemik. }
\end{aligned}
$$

Pendekatan adiwiyata merupakan segala upaya yang dilakukan untuk untuk menyisipkan lingkungan hidupke dalam suatu materi. Pendekatan adiwiyata ada 2 yaitu monolitik yaitu pendekatan yang dilakukan dengan cara materi lingkungan hidup dibuatkan 1 matapelajaran khusus pengelolaan dan perlindungan lingkungan hidup, sedangakan pendekatan integratif merupakan pendekatan yang dilakukan dengan cara menyisipkan perlindungan dan pengelolaan lingkungan hidup ke dalam materi. Pendekatan integratif ini dibutuhkan guru yang bisa mengembangkan materi dengan bagus agar semua materi bisa dikaitkan dengan lingkungan hidup.

\section{Manfaat Adiwiyata}

Keuntungan dari Program Adiwiyata di sekolah diantaranya. Menurut Tim Adiwiyata (2011) dalam Hidayati (2013) keuntungan mengikuti Program Adiwiyata sebagai berikut:

a. Menciptakan kebersamaan stakeholder dan situasi pada proses belajar mengajar yang kondusif dan lebih nyaman.

b. Mendukung (SKL) pendidikan dasar dan menengah.

c. Meningkatkan efesiensi dan penggunaan dana operasional di sekolah melalui pengurangan konsumsi dan penghematan dari berbagai sumber daya dan energi.

d. Meningkatkan upaya pengelolaan dan perlindungan lingkungan hidup 
melalui kegiatan kegiatan-kegiatan yang positif.

e. Nilai-nilai pemeliharaan dan pengelolaan lingkungan hidup di tempat pembelajaran yang baik dan benar stakeholders sekolah.

\section{METODE PENELITIAN}

Penelitian menggunakan jenis penelitian Kualitatif dengan pendekatan Studi kasus. Tempat penelitian adalah di SMP Pangudiluhur Sedayu. Subjek penelitian adalah kepala sekolah, waka kurikulum bagian kesiswaan, koordinator adiwiyata, guru yang pilih dengan cara purposive sampling dan peserta didik yang dipilih secara acak. Objek penelitian adalah dokumen kurikulum adiwiyata.

Teknik pengumpulan data yang digunakan adalah observasi, wawancara dan dokumentasi. Deskriptif kualitatif merupakan Tehnik analisis data yang digunakan dengan keabsahan data menggunakan triangulasi sumber.

\section{HASIL DAN PEMBAHASAN}

Adapun hasil yang di dapat dari penelitian telaah pengembangan kurikulum berbasis Adiwiyata di SMP Pangudiluhur Sedayu Yogyakarta yang berupa gambaran ke empat komponen kurikulum adalah :
Tabel. Gambaran pengembangan kurikulum berbasis Adiwiyata di SMP Pangudiluhur Sedayu

\begin{tabular}{|l|l|l|}
\hline No. & Aspek & \multicolumn{1}{|c|}{} \\
\hline 1. & Tujuan & $\begin{array}{l}\text { Menciptakan karakter peserta } \\
\text { didik yang cinta lingkungan } \\
\text { dan berbudaya kesenian yang } \\
\text { ada di Yogyakarta }\end{array}$ \\
\hline 2. & Isi & $\begin{array}{l}\text { Mata pelajaran yang } \\
\text { terintegrasi pendidikan } \\
\text { lingkungan hidup di } \\
\text { antaranya IPA, AGAMA, } \\
\text { Bahasa Inggris, Bahasa } \\
\text { Indonesia dan Bahasa Jawa }\end{array}$ \\
\hline 3. & Metode & $\begin{array}{l}\text { Guru menggunakan cara } \\
\text { mengajak siswa keluar kelas } \\
\text { dan praktik langsung agar } \\
\text { lebih peduli dan dekat dengan } \\
\text { lingkungan } \\
\text { Aspek yang di lihat adalah } \\
\text { kognitif dan psikomotorik }\end{array}$ \\
\hline 4. & Evaluasi \\
\hline
\end{tabular}

Berdasarkan hasil penelitian di atas, maka pembahasan penelitian dapat dijabarkan sebagai berikut:

\section{Pengembangan kurikulum}

Pada Sistem Pendidikan Nasional yang terdapat dalam UU No 20 tahun 2003 menyebutkan bahwa kurikulum merupakan suatu seperangkat pengaturan dan rencana yang terdapat tujuan, isi, dan bahan pelajaran serta cara yang digunakan sebagai pedoman yang digunakan sebagai pedoman penyelenggaraan pembelajaran untuk mencapai tujuan pendidikan tertentu. Dari 
pengertian ini di dapatkan dua dimensi kurikulum. Pertama rencana mengenai tujuan, isi, dan bahan pelajaran, dan yang kedua adalah segala sesuatu yang digunakan untuk kegiatan belajar dan mengajar. Kurikulum 2013 yang diberlakukan mulai tahun pelajaran 2016/2017 memenuhi kedua dimensi tersebut.

\section{Komponen Tujuan}

SMP Pangudiluhur Sedayu merupakan sekolah yayasan pangudiluhur. SMP Pangudiluhur Sedayu terletak di wates KM 12 daerah Yogyakarta. Selain itu SMP Pangudiluhur Sedayu merupakan salah satu SMP yang menerapkan program Adiwiyata di kabupaten Bantul di bawah pimpinan $\mathrm{BLH}$ (Badan Lingkungan Hidup) Kabupaten Bantul. SMP pangudiluhur Sedayu memiliki visi pribadi beriman, berwawasan lingkungan hidup, berbudaya, dan unggul dalam mutu. Hasil wawancara dengan wakil kepala sekolah bidang kurikulum Visi yang pertama yaitu pribadi beriman.

SMP pangudiluhur Sedayu selalu menjalankan perintah sesuai dengan ajaran dan keyakinan yang mereka anut seperti menghormati dan menghargai perbedaan dari masing-masing siswa dan guru yang terdapat di sekolah. Visi yang kedua yaitu berwawasan lingkungan SMP Pangudiluhur Sedayu selalu berusaha optimal untuk mewujudkannya dengan cara selalu
Memberikan pemahaman dan contoh kepada siswa dalam upaya peduli lingkungan di luar maupun di dalam kegiatan pembelajaran. Visi yang ke tiga di SMP Pangudiluhur yaitu berbudaya, berbudaya yang ada di SMP Pangudiluhur Sedayu adalah budaya memuat kegiatan cinta lingkungan dan budaya akan kesenian yang ada di wilayah DIY dan jawa pada umumnya misalnya, belajar bahasa kromo dan aksara jawa. Visi terakhir dari SMP Pangudiluhur Sedayu adalah unggul dalam mutu pada visi terakhir ini unggul dalam mutu yaitu siswa harus memiliki kompetensi dan prestasi baik non akademik maupun maupun akademik pada saat lulus dari SMP Pangudiluhur Sedayu supaya mampu bersaing di jenjang selanjutnya.

Berdasarkan visi sekolah tentunya misi sekolah harus saling berkaitan. SMP Pangudiluhur memiliki 1 misi untuk mencapai visi yang berkaitan dengan lingkungan. Misi SMP Pangudiluhur yang berkaitan dengan upaya peduli lingkungan adalah menumbuhkan keunggulan mutu secara bertahap dan peduli terhadap lingkungan. Upaya untuk mencapai misi dan menciptakan karakter peduli lingkungan tersebut SMP Pangudiluhur melakukan program sabtu bersih, membuat jadwal piket dan mengkondisikan lingkungan serta memberi motivasi pada siswa. Peneliti melakukan wawancara dengan wakasek Bidang Kurikulum mengenai visi dan misi 
sekolah untuk memaksimalkan program Adiwiyata untuk mewujudkan nilai karakter peserta didik SMP Pangudiluhur Sedayu yang dimana nilai karakternya adalah selalu cinta dan melindungi lingkungan:

"setiap siswa yang akan mengikuti mata pelajaran harus membawa sampah sebagai tiket masuk, sampab itu akan dikumpulkan dan buang oleh petugas piket".

Selain Program yang ada dilingkungan sekolah yang salah satunya adalah sabtu bersih untuk mewujudkan misi SMP pangudiluhur menjalin kerjasama dengan lembaga eksternal sekolah diantaranya adalah dengan badan lingkungan hidup, puskesmas, dan juga orang tua siswa guna mendukung kegiatan peduli lingkungan. "kami juga menjalin kerjasama dengan Badan Lingkungan Hidup, puskesmas, dengan usaha mandiri, dan juga orang tua siswa untuk dapat mendukung mewujudkan kegiatan peduli lingkungan" wakasek bagian kurikulum.

Program adiwiyata bertujuan menurut tim Adiwiyata adalah untuk menciptakan kondisi yang baik bagi warga sekolah dan untuk menjadikan tempat belajar bersama dan penyandaran warga sekolah, sehingga dikemudian hari warga sekolah tersebut dapat berturut-turut bertanggungjawab dalam upaya penyelamatan lingkungan bagi sekolah dasar dan menengah.

\section{Komponen Isi}

Implementasi kurikulum 2013 di SMP Pangudiluhur kelas VII, VIII dan IX. Muatan kurikulum SMP mencakup sejumlah mata pelajaran yang akan di tempuh oleh siswa dalam satu jenjang pendidikan selama tiga tahun mulai kelas VII sampai dengan kelas IX. Mata pelajaran SMP Pangudi luhur Sedayu terdiri 12 Mata pelajaran yang terdiri dari kelompok A. B , dan C. Dari 12 mata pelajaran di SMP Pangudiluhur Sedayu semuanya telah menyisipkan indikator peduli lingkungan. Berdasarkan wawancara yang dilakukan dengan narasumber TS bahwa "bampir semua mata pelajaran terintegrasi kedalam pendidikan lingkungan hidup diantaranya adalah IPA, Agama, Bahasa Inggris, Bahasa Indonesia, Bahasa Jawa”

Mata pelajaran yang sudah terintegrasi ke dalam indikator harus menyisipkan indikator lingkungan hidup itu secara tertulis di dalam RPP. Guru harus menyisipkan indikator lingkungan hidup ke dalam masing-masing RPP mereka. Berdasarkan wawancara dengan TS : bahwa:"guru yang sudah mata pelajaranya terintegrasi indikator lingkungan bidup harus tertuang di dalam RPP”

Berdasarkan triangalusi sumber dari wawancara dan juga observasi di dapatkan bahwa mata pelajaran di SMP Pangudiluhur sudah terintegrasi kedalam indikator muatan PLH adalah IPA, Agama, Bahasa Inggris, Bahasa Indonesia, Bahasa jawa. Mata 
pelajaran yang sudah terintegrasi harus tertuang pendidikan lingkungan hidup kedalam Rencana Pelaksaan Pembelajaraan ( RPP) masing-masing guru.

\section{Komponen Proses}

Metode yang dilakukan oleh guru menjadi salah satu aspek yang menjadi faktor penentu keberhasilan suatu program. Guru memegang peranan yang sangat penting untuk menentukan keberhasilan mewujudkan siswa yang peduli dan berkarakter lingkungan. akan tetapi tidak semua guru paham dan mampu mengembangkan metode yang akan di ajarkan untuk mencapai karakter siswa yang peduli lingkungan. Metode yang di lakukan guru bukan saja di dalam ruang kelas tetapi juga dilakukan di luar kelas.

Wawancara dengan TS bahwa: "Siswa biasanya lebih senang jïka praktek langsung diluar kelas ", misalnya pembuatan sampah organik pada materi biologi dan interaksi antara mahluk hidup yang saling menguntungkan.

Setiap guru mata pelajaran harus bisa mengkaitkan pelajaran yang mereka sampaikan dengan lingkungan. baik itu dari segi kehidupan sehari- hari, isu lokal dan juga isu global, semakin bagus guru mengembangkan indikator pendidikan lingkungan hidup maka potensi untuk menciptakan peserta didik yang berkarakter peduli lingkungan akan semakin besar. Hasil wawancara yang dilakukan dengan narasumber TS bahwa:"salah satu yang kami berikan contohnya seperti sampah, lingkungan pada saat setelah dibersibkan akan menjadi nyaman, kalau tidak dibersibkan tidak nyaman".

Berdasarkan triangulasi sumber melalui wawancara, guru selalu mengkaitkan materi dengan isu lokal dan global dan juga permasalahan lingkungan sehari-hari misalnya sampah. Siswa juga akan senang jika selalu di ajak keluar kelas atau menonton video di bandingkan dengan hanya mendengarkan materi saja.

\section{Komponen Evaluasi}

Setiap Sekolah yang sudah mengimplementasikan program Adiwiyata tentunya ingin membuat siswa siswinya ataupun alumni mereka memiliki karakter peduli lingkungan. Salah satu usaha sekolah adalah dengan mendukung sepenuhnya aktivitas guru atau siswa yang berkaitan dengan upaya peduli lingkugan, termasuk di SMP Pangudiluhur Sedayu. Selain itu, di SMP Pangudiluhur Sedayu, siswa juga diajak untuk membuat karya yang dibimbing langsung oleh guru. Karya yang dibuat berupa majalah dinding untuk publikasikan, puisi maupun pidato yang dimana itu akan meningkatkan keterampilan mereka.

Guru dan beserta siswa mempraktekkan secara langsung untuk membuat sebuah karya sebagai bentuk hasil dari pembelajaran yang dimana karya tersebut akan dikomunikasikan sebagai bentuk penghargaan seorang guru untuk 
siswa. Hasil wawancara dengan TS Bahwa: "karya yang di hasilkan oleh siswa dipasang di Lab IPA dan juga di mading, selain itu kami juga ingin membuat kompos lalu di jual', salah satu siswi yang saya wawancarai menambahkan bahwa: "kami membuat celengan dari botol bekas dan kami menghiasinya, selain itu karya di dalam pembelajaran akan dipresentasikan di dalam kelas dan juga di jendela kaca"

$$
\text { Berdasarkan Triangulasi sumber }
$$
melalui wawancara guru sudah mengembangkan kreatifitas siswa pada proses pembelajaran baik di dalam maupun diluar kelas untuk mendukung terwujudnya siswa yang peduli lingkungan. semakin banyak kreatifitas yang diajarkan oleh guru ke siswa maka akan semakin banyak juga karya yang dihasilkan oleh siswa. Karya yang sudah dihasilkan oleh siswa akan dipasang di ruang LAB IPA dan juga mading sekolah.

Salah satu manfaat dari program adwiyata adalah menjadi tempat pembelajaran tentang nilai-nilai pengelolaan lingkungan dan pemeliharaan yang baik dan benar bagi warga sekolah dan masyarakat sekitar. Pembelajaran dilaksanakan dengan maksimal maka akan memberikan dampak yang besar bukan saja buat warga sekolah tetapi juga buat warga sekitar sekolah. Seorang siswa bisa dinilai sudah melaksanakan program Adiwiyata dengan baik apabila sudah ada indikator peduli lingkungan yang sudah melekat pada siswa. Berdasarkan wawancara koordinator bidang
Adiwiyata bahwa "aspek yang kami nilai dalam diri siswa terkait dengan pembelajaran hidup adalah pengetahuan dan prakteknya “ Karena aspek kognitif dan psikomotorik di SMP Pengudilubur Sedayu sudah mewakili peduli dan berkarakter lingkungan"

\section{KESIMPULAN}

Kesimpulan artikel ini adalah pengembangan kurikulum idealnya memuat empat (4) komponen yang terdiri dari tujuan, isi, proses, dan evaluasi. Masingmasing komponen memiliki keunggula integrasi dari program adiwiyata untuk mendukung sustainable development goals. Upaya peduli lingkungan sebagai salah satu program yang dapat diterapkan. Masingmasing komponen yang dikembangkan berbasis adiwiyata ini memiliki keunggulan, misalnya komponen tujuan membahas mengenai visi misi sekolah yang berkaitan dengan upaya mewujudkan sekolah yang peduli lingkungan. Komponen isi menyiapkan materi pelajaran yang sudah terintegrasi dengan upaya peduli lingkungan. Komponen metode membahas tentang cara guru menyampakan materi yang memuat upaya untuk menjadikan siswa peduli lingkungan, serta komponen evaluasi membahas mengenai aspek yang akan dicapai siswa saat impelemntasi kurikulum berbasis adiwiyata.

Dampak dari pengembangan kurikululm berbasis adiwiyata ini para lulusan semakin cinta lingkungan, 
memahami kondisi lingkungan, dan mampu memperhatikan lingkungan. Kesadaran nyata akan lingkungan melekat pada diri para lulusan, sehingga pengembangan kurikulum berbasis wiyata sangat dibutuhkan bagi siapapun terutama pada siswa supaya dapat meningkatkan pemahaman mengenai pengelolaan lingkungan dan seni bertahan hidup dengan lingkungan.

Kelemahan dari pelaksanaan adiwiyata yang didapatkan antara lain 1) fasilitas yang kurang lengkap untuk mendukung kegiatan siswa dan guru 2) tidak semua komptensi dasar bisa dikaitkan dengan lingkungan 3) masih banyaknya siswa yang membuang sampah bukan pada tempatnya.

\section{REFERENSI}

Adam, Ahmad fajarisma budi. 2014. "Analisis Implementasi Kebijakan Kurikulum Berbasis Lingkungan Hidup Pada Program Adiwiyata Mandiri di SDN Dinoyo 2 Malang”. Jurnal Kebijakan dan Pengembangan Pendidikan. Vol. 2 (2). Hal. 166-173.

Afakhrul Masub dan Arya Setya Nugroho. 2016. "Curriculum Development of Environmental Education Based on Local Wisdom at Elementary School". International Journal of Learning, Teaching and Educational Research. Vol. 15 (3). Hal. 20-28.
Alpusari, Mahmud. 2013. “Analisis Kurikulum Pendidikan Lingkungan Hidup Pada Sekolah Dasar Pekanbaru". Jurnal Primary Program Studi Pendidikan Guru Sekolah Dasar Fakultas Keguruan dan Ilmu Pendidikan Universitas Riau. Vol. 2 (2). Hal. 1017.

Arifin, Zainal. 2012. Konsep dan Model pengembangan Kurikulum. Bandung : PT. Remaja Rosdakarya.

Arifin, Zainal. 2014. Konsep dan Model pengembangan Kurikulum. Bandung : PT. Remaja Rosdakarya

Bakhtiar, Afakhrul Masub dan Arya Setya Nugroho. 2016. “Curriculum Development of Environmental Education Based on Local Wisdom at Elementary School". International Journal of Learning, Teaching and Educational Research. Vol. 15 (3). Hal. 20-28.

Hakim, M. N., \& Hasan, M. T. (2019). Inovasi Kurikulum Pendidikan SMA Darul Ulum 2 di Pondok Pesantren Darul Ulum Jombang. Jurnal Manajemen Pendidikan Islam Al-Idarah, 4(2), 1-13.

Hamalik, Oemar. 2014. Kurikulum dan Pembelajaran. Jakarta :BumiAksara.

Hayati, Sri. 2017. Pendidikan Lingkungan Hidup (PLH) dalam Membentuk Perilaku 
Herdiansyah, Haris. 2015. Wawancara, Observasi, dan Focus Groups. Jakarta :Rajawali Press.

Iswari, R. D., \& Utomo, S. W. (2017). Evaluasi Penerapan Program Adiwiyata Untuk Membentuk Perilaku Peduli Lingkungan di Kalangan Siswa (Kasus: SMA Negeri 9 Tangerang Selatan dan MA Negeri 1 Serpong). Jurnal Ilmu Lingkungan, 15(1), 35. https://doi.org/10.14710/jil.15.1.35 $-41$

Nasution. 2014. Asas-Asas Kurikulum. Jakarta : Bumi Aksara.

Nihlawati,siti. 2017. "Substansi Kebijakan Kurikulum Berbasis Lingkungan pada Sekolah Adiwiyata di SMPN 2 Kebomas gresik". Jurnal Pemikiran Pendidikan. Vol. 18 (22) hal 12

Nurhayati, Ela. 2015. "Implementasi Kurikulum Berbasis Lingkungan Di Sekolah Adiwiyata (Studi Kasus Di Smp Negeri 16 Surabaya)". Jurnal Manajemen Pendidikan. Hal. 1-15.

Permendikbud No 5 Tahun 2013 Tentang panduan pelaksanaan Adiwiyata

Susilawati, W. O., \& Widodo, H. (2019). Strategy of Teachers in Planting Character Care for Student Environment in SMK Muhammadiyah Pakem. Journal of Education and Learning (EduLearn),
13(2),

247-

254.https://doi.org/10.11591/edule arn.v13i2.12167

Susilo, Muhamad Joko. 2007. Kurikulum Tingkat Satuan Pendidikan. Yogyakarta: pustaka pelajar

Tim Adiwiyata Tingkat Nasional, 2012. Panduan Adiwiyata Sekolah Peduli dan Berbudaya Lingkungan. Jakarta : Asdep Urusan Penguatan Inisiatif Masyarakat Deputi Bidang Komunikasi Lingkungan dan Pemberdayaan Masyarakat, Kementrian Lingkungan Hidup. Hal. 3-4

Tim Pengembang MKDP. 2017. Kurikulum Dan Pembelajaran. Depok. : Rajawali Pers.

Undang-Undang Nomor 20 Tahun 2003 Tentang Pendidikan Nasional. UU No. 32 Tahun 2009 pasal 1 ayat 2. 